\title{
PENOMORAN DAN PENANGGALAN AKTA NOTARIS BERDASARKAN PUTUSAN PENGADILAN (ANALISIS PUTUSAN PN DENPASAR NOMOR 530/PDT. G/2016/PN. DPS.)
}

\author{
Istadevi Utami Rahardika, I Nyoman Gede Sugiartha, Putu Ayu Sriasih Wesna \\ Fakultas Ilmu Hukum Universitas Warmadewa, Denpasar-Bali, Indonesia \\ istadevi04@gmail.com, nyomansugiartha14@gmail.com ayuwesna@gmail.com
}

\begin{abstract}
Abstrak
Pengadilan Negeri Denpasar (PN) dalam putusannya Nomor 530/ Pdt.G/2016/PN.Dps menyatakan menghukum Notaris untuk segera memberi nomor dan tanggal pada Akta Perjanjian Pengikatan Jual Beli dan Akta Kuasa. Hal tersebut menarik dan penting untuk dikaji dalam penelitian ini terkait dengan dasar kewenangan dan cara pemberian nomor dan tanggal akta yang telah ditandatangani oleh para pihak dihadapan Notaris setelah putusan PN Denpasar. Penelitian hukum normatif ini bertujuan untuk mengkaji isi dari tataran hukum positif, tentang Penomoran dan Penanggalan Akta Notaris, dengan menggunakan bahan hukum primer, sekunder dan tersier, sementara itu metode analisis menggunakan cara interpretasi gramatikal, dan sistematis. Hasil penelitian menunjukkan bahwa dasar kewenangan PN Denpasar memutuskan sengketa tentang Penomoran dan Penanggalan akta Notaris yakni Pasal 130 HIR/154 Rbg, Pasal 1851 KUH.Perdata, UU RI Nomor 48 Tahun 2009, Perma RI Nomor 1 Tahun 2016, dan asas ius curia novit. Sehubungan dengan penomoran dan penanggalan terhadap akta Notaris dapat dilakukan berdasarkan ketentuan UUJNP dan merujuk pada putusan PN Denpasar.
\end{abstract}

Kata Kunci: Penomoran dan Penanggalan, Notaris, Akta Perjanjian Pengikatan Jual Beli, Putusan Pengadilan.

\begin{abstract}
The Denpasar District Court (PN) in its decision Number 530 / Pdt.G / 2016 / PN.Dps stated that it has punished the Notary to immediately give the number and date to the Sale and Purchase Binding Agreement Deed and the Power of Attorney. This is interesting and important to examine in this research in relation to the basis of authority and the method of assigning the number and date of the deed signed by the parties before the notary after the Denpasar District Court decision. This normative legal research aims to examine the contents of a positive legal level, concerning the Numbering and Dating of Notary Deeds, using primary, secondary and tertiary legal materials, while the analysis method uses grammatical and systematic interpretation. The results showed that the basic authority of the Denpasar District Court to decide disputes regarding the numbering and dating of notary deeds, namely Article 130 HIR / 154 Rbg, Article 1851 of the Civil Code, Law of the Republic of Indonesia Number 48 of 2009, Perma RI Number 1 of 2016, and the principle of ius curia novit. In connection with the numbering and dating of the Notary deed, it can be done based on the provisions of the UUJNP and refers to the Denpasar District Court decision.
\end{abstract}

Keywords: Numbering and Dating, Notary, Deed of Sale and Purchase Agreement, Court Decision.

\section{PENDAHULUAN}

Salah satu kewenangan Notaris sebagai pejabat umum adalah berwenang membuat akta autentik. Sementara itu, menurut Laksana \& Griadhi (2019) akta Notaris adalah akta autentik yang dibuat oleh atau di hadapan Notaris menurut bentuk dan tata cara yang ditetapkan dalam Pasal 38 ayat (1) UUJNP yang menyebutkan bahwa setiap akta terdiri atas (a) awal akta, (b) badan akta dan (c) akhir atau penutup akta.

Akta Notaris mesti memenuhi syarat formal dalam pembentukannya, akibat hukumnya jika syarat formal tidak dipenuhi, baik sebagian atau seluruhnya sebagaimana disyaratkan Pasal 38 UUJN-P, adalah akta Notaris tersebut hanya mempunyai kekuatan pembuktian sebagai tulisan di bawah tangan, jika ditandatangani oleh para pihak sebagaimana juga ditegaskan dalam Pasal 1869 KUH Perdata. Dengan mengacu pada istilah Sjaifurrachman dalam satu tulisannya menyebut akta Notaris yang hanya mempunyai kekuatan pembuktian sebagai tulisan di bawah tangan disebut dengan istilah degradasi akta (Sjaifurrachman, 2011). 
Pasal 38 (1) huruf a UUJN-P menyebutkan bahwa setiap awal Akta atau kepala Akta memuat a. judul Akta, b. nomor Akta, c. jam, hari, tanggal, bulan, dan tahun; dan d. nama lengkap dan tempat kedudukan Notaris. Salah satu aspek penting dari awal akta Notaris yakni mesti mencantumkan nomor akta yang dibuat dengan angka arab, ditulis setelah penulisan judul akta dilanjutkan dengan penomoran dan penanggalan akta. Penomoran dan penanggalan akta dikatakan penting karena pada satu sisi terkait dengan otentisitas akta Notaris, dan pada sisi yang lain bersifat administratif karena terkait dengan kewajiban Notaris untuk setiap hari mencatat semua akta yang dibuat oleh atau di hadapannya.

Bentuk dan sifat akta sebagaimana diuraikan dalam Pasal 38 UUJN-P mesti mendapat perhatian yang serius dari Notaris dalam pembuatan akta agar akta tersebut dapat dikatakan sebagai akta otentik. Oleh karena itu, ketika akta dibuat harus dapat menjamin adanya kepastian waktu sebagai salah satu syaratnya. Kepastian waktu pembuatan akta merupakan hal yang mendasar bagi para pihak untuk menetapkan atau menentukan kapan suatu perjanjian atau perbuatan hukum itu dibuat dan disepakati di antara para pihak pembuatnya. Kepastian waktu akan semakin jelas, jika pada saat itu akta Notaris tersebut juga disertai dengan penomoran atau dengan kata lain penundaan penomoran akta akan berimplikasi pada pemunduran waktu atau tanggal dibuatnya akta tersebut.

Penomoran dan Penanggalan Akta Notaris, menjadi menarik dan penting untuk dikaji karena ada satu kasus di Pengadilan Negeri Denpasar sebagaimana tertuang dalam putusan Nomor 530/Pdt.G/2016/PN.Dps., tertanggal 12 Oktober 2016 yang secara garis besar telah memeriksa dan mengadili dalam perkara Perdata, dengan tergugatnya adalah seorang Notaris dan PPAT di Kabupaten Badung, Wilayah Jabatan Provinsi Bali. Dari proses pemeriksaan perkara perdata tersebut, Tergugat bersedia dan sepakat untuk mengakhiri persengketaan dengan jalan perdamaian melalui proses mediasi dengan salah satu Hakim Pengadilan Negeri Denpasar ditunjuk sebagai mediator.

Isi putusan perdamaian yang dibuat dan disepakati oleh penggugat dan Notaris selaku tergugat, yaitu: Pihak kedua sebagai Pejabat Notaris yang ditunjuk setuju dan bersedia untuk segera menyelesaikan proses Akta Perjanjian Pengikatan Jual Beli (PPJB) dan Akta Kuasa atas bidang-bidang tanah obyek sengketa yang telah ditandatangani oleh Pihak Pertama dengan masing-masing pemilik tanah sesuai dengan prosedur dan aturan hukum yang berlaku bedasarkan UU No. 2 Tahun 2014 tentang perubahan atas UU No. 30 Tahun 2004 tentang Jabatan Notaris dengan segera memberi nomor dan tanggal pada Akta Perjanjian Pengikatan Jual Beli (PPJB) dan Akta Kuasa, sehingga Salinan akta Perjanjian Pengikatan Jual Beli (PPJB) dan Salinan Akta Kuasa atas masing-masing bidang tanah dapat segera diterbitkan.

Ihwal diatas menunjukkan bahwa penomoran dan penanggalan akta Notaris bisa terjadi karena 2 (dua) hal yaitu, menurut ketentuan UUJN-P, dan kedua, karena Putusan Pengadilan. Sehubungan dengan hal tersebut penelitian ini bertujuan untuk mengetahui kewenangan Pengadilan Negeri Denpasar di dalam memutuskan sengketa terkait penomoran dan penanggalan terhadap akta Notaris yang telah ditandatangani para pihak dihadapan Notaris sebagaimana Putusan Nomor 530/Pdt.G/2016/PN.Dps dan mengetahui penomoran dan penanggalan terhadap akta yang telah ditandatangani oleh para pihak dihadapan Notaris setelah ditetapkannya putusan Pengadilan Negeri Denpasar Nomor 530/Pdt.G/2016/PN.Dps.

\section{METODE PENELITIAN}

Penelitian ini merupakan penelitian normatif atau penelitian ilmu hukum dogmatik karena mengkhususkan pada aturan-aturan hukum positif tertentu dan asas-asas hukum. Menurut Hadjon (1994), lebih jauh disebutkan bahwa karakter penelitian ini tergolong pada penelitian ilmu hukum dogmatik. Sifat dogmatik dari penelitian ini adalah mengkaji isi dari tataran hukum positif yang berkaitan dengan Penomoran dan Penanggalan Akta Notaris berdasarkan Putusan Pengadilan.

Sesuai dengan karakter penelitian ini yang bersifat normatif, maka pendekatan yang digunakan adalah pendekatan perundang-undangan (the statute approach) dan pendekatan konsep hukum Penelitian ini didukung oleh kasus yang terjadi di Pengadilan Negeri Denpasar, sehingga tipe penelitiannya tergolong case study design (studi kasus). Ini berarti pendekatan yang digunakan dalam penelitian ini adalah pendekatan kasus (case approach) terkait dengan ratio decidendi, (conceptual approach) (Marzuki, 2013).

Bahan hukum yang digunakan dalam penelitian ini terdiri dari bahan hukum primer merupakan bahan hukum yang mempunyai kekuatan mengikat berupa norma-norma, peraturan perundangundangan nasional, dan putusan pengadilan, bahan hukum sekunder merupakan bahan yang 
memberikan penjelasan mengenai bahan hukum primer berupa jurnal hukum, buku hukum yang berkaitan dengan pembahasan ini, dan pendapat para pakar hukum atau doktrin, dan bahan hukum tersier merupakan bahan hukum yang dapat memberikan penjelasan terhadap bahan hukum primer maupun bahan hukum sekunder yang berupa kamus hukum, ensiklopedia dan kamus besar bahasa Indonesia (Soekanto \& Mamudji, 2001).

Sementara itu untuk teknik pengumpulan bahan hukum dilakukan dengan metode bola salju (snowball method), artinya bahan hukum dikumpulkan melalui beberapa literatur kemudian dari beberapa literatur tersebut diambil sejumlah sumber yang mendukung literatur tersebut. Adapun analisis bahan hukum dilakukan dengan menggunakan metode interpretasi berupa interpretasi gramatikal, dan interpretasi sistematis. Interpretasi gramatikal adalah menafsirkan kata-kata atau interpretasi menurut arti perkataan dalam perspektif kaidah bahasa dan kaidah hukum tata bahasa yang berlaku dalam peraturan perundang-undangan termasuk putusan pengadilan yang relevan untuk mengkaji permasalahan dalam penelitian skripsi ini. Sedangkan interpretasi sistematis memandang aturan hukum yang satu dengan aturan hukum yang lainnya saling berkaitan, dan senantiasa terhubung sebagai suatu sistem yang tidak dapat ditafsirkan seakan-akan berdiri sendiri.

\section{HASIL DAN PEMBAHASAN}

\section{Pengaturan Kewenangan Pengadilan Negeri Denpasar terkait dengan Putusan Perkara} Perdata Nomor 530/Pdt. G/2016/PN. Dps

Pengaturan kewenangan Pengadilan Negeri berdasarkan pada ketentuan UU Nomor 8 Tahun 2004 (LNRI Tahun 2004 Nomor 34, TLN RI 4379) tentang Perubahan Atas UU Nomor 2 Tahun 1986 tentang Peradilan Umum dan perubahan berikutnya dengan UU Nomor 48 Tahun 2009 (LNRI Tahun 2009 Nomor 158, TLN RI 5007) tentang Perubahan Kedua Atas UU Nomor 2 Tahun 1986 tentang Peradilan Umum, yang dilatar belakangi dengan adanya Putusan Mahkamah Konstitusi Nomor 005/PUU-IV/2006 tanggal 23 Agustus 2006.

Kompetensi absolut Pengadilan Negeri yakni bertugas dan berwenang memeriksa, memutus, dan menyelesaikan perkara pidana dan perkara perdata di tingkat pertama. Sejalan dengan hal tersebut, maka pengadilan dilarang menolak untuk memeriksa, mengadili, dan memutus suatu perkara yang diajukan dengan dalih bahwa hukum tidak ada atau kurang jelas, melainkan wajib untuk memeriksa dan mengadilinya, namun tidak menutup usaha penyelesaian perkara perdata secara perdamaian. Dalam doktrin hukum acara perdata disebut asas ius curia novit. Sementara itu Yahya Harahap dalam bukunya Hukum Acara Perdata tentang Gugatan, Persidangan, Penyitaan, Pembuktian dan Putusan Pengadilan menjelaskan bahwa ius curia novit artinya hakim dianggap mengetahui semua hukum sehingga Pengadilan tidak boleh menolak memeriksa dan mengadili perkara (Harahap, 2016).

Menggunakan interpretasi sistematis, pengaturan perdamaian dapat dijumpai dalam Pasal 130 HIR / 154 Rbg sebagai sumber hukum acara perdata dan Pasal 1851 KUH Perdata. Hakikat Pasal 130 HIR / 154 Rbg menetapkan jika pada hari sidang yang telah di tetapkan dan dihadiri oleh kedua belah pihak, maka hakim harus berusaha mendamaikan mereka. Kehadiran hakim pada saat inilah berperan secara aktif dan dalam kerangka memberikan kesempatan bagi kedua belah pihak untuk keperluan tercapainya upaya perdamaian, lazim dilakukan oleh hakim adalah mengundurkan jadwal sidang tersebut.

Secara prosedural penyelesaian sengketa melalui perdamaian sebagaimana diatur dalam Pasal 130 HIR/154 Rbg dan Pasal 1851 KUH Perdata, mesti memenuhi persyaratan yakni (1) adanya persetujuan kedua belah pihak yang bersengketa, (2) putusan perdamaian didasarkan pada sengketa yang telah ada, (3) persetujuan perdamaian harus dituangkan dalam bentuk tertulis, dan putusan perdamaian (dading) mengakhiri sengketa yang timbul. Ada beberapa kriteria untuk dapat melaksanakan upaya perdamaian (dading) di depan persidangan, ada beberapa syarat yang harus diperhatikan oleh para pihak yang sedang bersengketa yaitu (1) harus ada kesepakatan diantara para pihak yang sedang bersengketa, (2) perdamaian dituangkan dalam putusan hakim untuk mengakhiri sengketa para pihak, (3) perdamaian yang disepakati oleh para pihak terhadap sengketa yang sedang terjadi, (4) isi perdamaian yang telah disepakati oleh para pihak wajib dibuat dalam bentuk tertulis.

Kesepakatan di antara para pihak yang sedang bersengketa, mesti tunduk pada kaidah-kaidah keabsahan hukum perjanjian sebagaimana di maksud di dalam pasal 1320 KUH Perdata, dan dilakukan dengan iktikad baik, sebagaimana dirumuskan pada Pasal 1338 ayat (3) KUH Perdata. 
Perdamaian dituangkan dalam putusan hakim dengan maksud untuk mengakhiri sengketa para pihak secara menyeluruh dan tuntas, sebagaimana diatur di dalam Pasal 1858 KUH Perdata, yang menegaskan bahwa putusan akta perdamaian memiliki kekuatan sama seperti putusan hakim yang telah berkekuatan hukum tetap, kecuali perdamaian itu dilakukan dengan cara penipuan, paksaan, sebagaimana dimaksud di dalam Pasal 1859 KUH Perdata.

Peraturan Mahkamah Agung Republik Indonesia Nomor 1 Tahun 2016 tentang Prosedur Mediasi di Pengadilan. Lahirnya Peraturan Mahkamah Agung dimaksudkan untuk mendorong Para Pihak menempuh proses perdamaian melalui Mediasi dengan mengintegrasikannya ke dalam prosedur berperkara di Pengadilan. Dengan berlakunya Peraturan Mahkamah Agung Republik Indonesia Nomor 1 Tahun 2016 Tentang Prosedur Mediasi di Pengadilan maka sesuai dengan ketentuan yang diatur pada Pasal 38 menyebutkan bahwa Peraturan Mahkamah Agung Nomor 01 Tahun 2008 tentang Prosedur Mediasi di Pengadilan dicabut dan dinyatakan tidak berlaku. Semua sengketa perdata yang diajukan ke Pengadilan termasuk perkara perlawanan (verzet) atas putusan verstek dan perlawanan pihak berperkara (partij verzet) maupun pihak ketiga (derden verzet) terhadap pelaksanaan putusan yang telah berkekuatan hukum tetap, wajib terlebih dahulu diupayakan penyelesaian melalui Mediasi kecuali terhadap sengketa perdata sebagaimana yang diatur pada Pasal 4 ayat (2) Peraturan Mahkamah Agung Republik Indonesia Nomor 1 Tahun 2016.

Putusan Pengadilan Negeri Denpasar Nomor 530/Pdt.G/2016/PN. Dps. tertanggal 2 Agustus 2016, dengan jalan perdamaian melalui proses mediasi terkait dengan dokumen transaksi jual beli berupa Akta Perjanjian Pengikatan Jual Beli (selanjutnya disingkat PPJB) dan Akta Kuasa yang dibuat dihadapan WAYAN DARMA WINATA selaku Notaris di Kabupaten Badung, karena tidak terlaksananya kelanjutan proses jual beli dan proses peralihan hak atas bidang-bidang tanah obyek sengketa yang telah dibeli dan dibayarkan lunas oleh Pihak Pertama.

Pihak Kedua dalam kedudukannya sebagai Notaris dan PPAT yang ditunjuk dan diberi kuasa untuk melanjutkan proses jual beli dan proses peralihan hak menjadi atas nama Pihak Pertama, telah melakukan tindakan yang bertentangan dengan hukum yang berlaku yaitu tidak dengan segera memberikan nomor dan tanggal pada Akta PPJB maupun Akta Kuasa yang telah ditandatangani oleh Pihak Pertama sebagai pembeli dengan masing-masing pemilik tanah.

Amar putusan Pengadilan Negeri Denpasar juga ditegaskan bahwa Pihak Pertama / Penggugat telah melakukan pembayaran pelunasan, sehingga dengan telah terpenuhi seluruh hak-hak penjual maka proses peralihan hak atas tanah yang menjadi obyek sengketa sudah seharusnya segera dilakukan proses peralihan haknya menjadi atas nama pembeli. Ini berarti bahwa Pihak Pertama telah memenuhi janji-janji yang disebutkan di dalam PPJB, namun Pihak Kedua dipandang lalai karena tidak melaksanakan kewajiban sebagaimana yang telah diatur secara hukum sebagai Notaris/PPAT dan tindakan Pihak Kedua dipandang bertentangan dengan hukum yang berlaku, sehingga mengakibatkan kerugian bagi Pihak Pertama.

Suatu Tindakan dipandang bertentangan dengan hukum, lazim disebut sebagai perbuatan melanggar hukum, artinya merupakan perbuatan yang menimbulkan kerugian, dan secara normatif perbuatan tersebut tunduk pada ketentuan Pasal 1365 KUH Perdata. Adapun mengenai bentuk tanggung gugat yang dianut oleh Pasal 1365 ini adalah tanggung gugat berdasarkan kesalahan (liability based fault) (Sjaifurrachman, 2011).

Upaya penyelesaian sengketa perdata antara Pihak Pertama / Penggugat dengan Pihak Kedua / Tergugat menghasilkan kesepakatan dan saling mengikatkan diri untuk menyelesaikan permasalahan hukum secara musyawarah dan mufakat untuk perdamaian, sejalan dengan rumusan ketentuan Pasal $130 \mathrm{HIR} / 154 \mathrm{Rbg}$, yang secara garis besar menentukan bahwa jika pada hari sidang yang telah ditetapkan kedua belah pihak hadir, maka hakim harus berusaha mendamaikan mereka

Putusan yang dijatuhkan oleh hakim sehubungan dengan pokok perkara No. 530/Pdt.G/2016/PN.Dps., secara musyawarah dan mufakat untuk perdamaian dimaksudkan untuk mengakhiri perkara pada tingkat pertama di Pengadilan Negeri Denpasar antara Pihak Pertama / Penggugat dengan Pihak Kedua / Tergugat. Kesepakatan perdamaian tersebut dinyatakan dalam bentuk putusan hakim yang jika dilihat dari amar putusannya dapat dikualifikasi sebagai putusan akhir yang bersifat menghukum (condemnatoir) (Rifai, 2010). Namun, dengan adanya Putusan Pengadilan Negeri Denpasar dengan pokok perkara No. 530/Pdt.G/2016/PN.Dps., menurut penulis dimaksudkan untuk mengembalikan kepada dasar pertimbangan dibuatnya UUJN-P yaitu menjamin kepastian, ketertiban, dan perlindungan hukum bagi setiap warga negara melalui alat bukti tertulis yang bersifat 
autentik mengenai perbuatan, perjanjian, penetapan, dan peristiwa hukum yang dibuat dihadapan atau oleh Notaris sebagai pejabat umum yang berwenang.

Penomoran dan penanggalan kembali Akta PPJB dan Akta Kuasa Menjual dengan putusan Pengadilan Negeri Denpasar tersebut juga akan meniadakan sifat melawan hukum dari Notaris di dalam membuat Akta Perjanjian Pengikatan Jual Beli dan Kuasa (Pihak Kedua / Tergugat) dan termasuk dalam kerangka memberikan kepastian tanggal pembuatan akta sebagaimana dimaksud di dalam ketentuan pasal 15 ayat (1) UUJN-P. Ini berarti penekanan pada asas kepastian hukum, lebih cenderung untuk mempertahankan norma-norma hukum tertulis dari hukum positif yang ada untuk memberikan perlindungan hukum bagi setiap warga negara dan terhadap Notaris sebagai Pejabat Umum yang menjalankan profesi dalam memberikan jasa hukum kepada masyarakat.

Peniadaan sifat melawan hukum yang dimaksud menurut pandangan penulis adalah peniadaan sifat melawan hukum secara keperdataan dan sifat melawan hukum secara pidana. Ini berarti dengan putusan pengadilan tersebut, Akta PPJB dan Akta Kuasa Menjual menjadi tidak kehilangan otentisitasnya. Otentisitas Akta PPJB dan Akta Kuasa Menjual sebagai bagian dari akta notaris terkait dengan tata cara pembuatannya memenuhi prosedur dan persyaratannya sesuai ketentuan UUJN.

Terpenuhinya autentisitas khususnya aspek penomoran dan penanggalan Akta PPJB dan Akta Kuasa Menjual maka Notaris (Pihak Kedua/Tergugat) dapat mengeluarkan salinan Akta Perjanjian Pengikatan Jual Beli (PPJB) dan salinan Akta Kuasa untuk melakukan proses peralihan hak atas tanah menjadi atas nama Pihak Pertama/Penggugat dengan terlebih dahulu melakukan kewajiban perpajakannya dilanjutkan dengan penandatanganan Akta Jual Beli (AJB) atas masing-masing tanah obyek sengketa sesuai dengan prosedur dan aturan hukum yang berlaku di hadapan pejabat PPAT yang ditunjuk oleh Pihak Kedua sesuai dengan wilayah hukum bidang-bidang tanah obyek sengketa, yang ditandatangani oleh dan antara Pihak Pertama sebagai Pembeli dan sekaligus sebagai Penjual berdasarkan salinan Akta Kuasa masing-masing bidang tanah untuk memenuhi ketentuan pasal 2 Putusan Pengadilan Negeri Denpasar dengan pokok perkara No. 530/Pdt.G/2016/PN.Dps., tertanggal 20 Oktober 2016.

\section{Cara Penomoran dan Penanggalan Kembali Perjanjian Pengikatan Jual Beli dan Kuasa setelah berlakunya Putusan Pengadilan Negeri Denpasar Nomor 530/Pdt.G/2016/PN. Dps}

Perjanjian pengikatan jual beli adalah perjanjian yang timbul karena kesepakatan dua pihak atau lebih dengan tujuan timbulnya perikatan untuk kepentingan yang satu atas beban yang lain atau disebut juga dengan perjanjian timbal balik dilihat dari aspek sifat dan akibat hukumnya, dan pada sisi lain disebut sebagai perjanjian bantuan (Budiono, 2018). Sebagai perjanjian bantuan maka fungsinya adalah untuk mempersiapkan para pihak pada perjanjian utama, yang tujuan akhirnya adalah pada perjanjian pokoknya, yakni perjanjian jual beli. Sejalan dengan hal tersebut Herlien Boediono menjelaskan bahwa perjanjian bantuan sifatnya memperkuat perjanjian pokok dan keberadaannya pun hanya mungkin jika perjanjian pokoknya ada (Budiono, 2011).

Dikaji dari aspek sumber wewenang maka Notaris dalam menjalankan jabatannya mendapatkan kewenangan yang bersumber dari undang-undang maka kewenangan Notaris tersebut bersifat atributif, artinya pemberian wewenang oleh pembuat undang-undang kepada Notaris sebagai salah satu pelaksana urusan pemerintahan di bidang hukum perdata. Penggunaan wewenang Notaris dalam membuat akta autentik harus memenuhi ketentuan yang diatur di dalam pasal 38 UUJN-P, yang terdiri dari (a) awal Akta atau kepala Akta, (b) badan Akta dan (c) akhir atau penutup Akta.

Notaris sebagai pejabat umum wajib mencantumkan pada awal akta atau kepala akta tentang kebenaran dilaksanakannya pembuatan akta notaris yang secara kronologis logis merupakan fakta hukum dan diuraikan sebagaimana diharuskan di dalam Pasal 38 ayat (2) UUJN-P. Pencantuman uraian fakta di dalam kepala akta, dengan cara mengonstatir fakta dan menuliskannya pada bagian awal akta untuk memenuhi ketentuan Pasal 38 UUJN-P. Jika tidak demikian maka akibat hukumnya adalah akta Notaris akan kehilangan autentisitasnya dan hanya mempunyai kekuatan pembuktian sebagai akta di bawah tangan apabila ditandatangani oleh para pihak.

Pasal 38 ayat (2) huruf a dan b UUJN-P mewajibkan setiap akta Notaris diberi nomor pengeluarannya atau penerbitannya oleh Notaris yang membuatnya. Pasal tersebut dan di pasal-pasal lainnya tidak ada ketentuan mengenai penomoran akta Notaris, hanya ada beberapa kebiasaan Notaris yang bisa dijadikan pedoman, yaitu (1) Akta notaris wajib diberi nomor secara berurut dimulai dari nomor satu dan seterusnya untuk setiap bulan, selanjutnya pada bulan berikutnya diulang Kembali dari 
nomor satu. Penulisan nomor akta dengan numerik latin yang dimulai dari satu digit, namun ada juga yang menggunakan dua digit.

Pencantuman jam/pukul pada akta merupakan waktu atau momentum para pihak menghadap Notaris, dan harus disesuaikan dengan pembagian wilayah waktu di Indonesia serta tempat kedudukan Notaris. Sementara itu, menarik yang disampaikan Herlien Budiono, dalam salah satu tulisannya yang menyebutkan bahwa di Nederland, notaris tidak berkewajiban untuk mencantumkan jam (tijdstip) dilaksanakannya pembuatan akta, khususnya pada waktu pembacaan penandatanganan akta notaris, kecuali untuk pembuat yang diharuskan untuk didaftarkan di dalam register umum (openbare register) (Budiono, 2011). Selanjutnya Notaris harus menjamin tanggal dari akta, artinya bahwa tanggal yang disebut dalam akta adalah tanggal diresmikannya akta, yaitu dibuatnya akta, dibacakannya oleh Notaris dan ditandatanganinya oleh para penghadap saksi-saksi dan Notaris. Karena itu tanggal ini tidak boleh berlainan dengan tanggal diresmikannya akta, jadi tidak boleh diadakan apa yang disebut anti dateren", ialah memberi tanggal yang lain daripada tanggal peresmian (verlijden) akta (Notodisoejo, 1982). Kepastian tentang tanggal ini kadang-kadang besar sekali artinya, umpamanya untuk suatu perjanjian dimana diikatkan suatu jangka waktu tertentu, terutama apabila jangka waktu itu dihitung mulai daripada tanggal akta yang bersangkutan.

Deskripsi tersebut maka penomoran dan penanggalan akta Notaris menurut ketentuan UUJNP yang dilakukan oleh Notaris dengan maksud untuk menjamin kepastian hari, tanggal, bulan, tahun dan pukul menghadap yang tercantum atau disebutkan pada bagian awal akta Notaris, sebagai bukti bahwa para pihak menghadap dan menandatangani akta pada hari, tanggal, bulan, tahun dan pukul yang tersebut dalam akta dan semua prosedur pembuatan telah dilakukan sesuai aturan hukum yang berlaku. Selanjutnya, masalah penomoran dan penanggalan akta merupakan bagian dari anatomi akta secara keseluruhan sehingga hal tersebut mesti ditafsirkan merupakan satu kesatuan dengan bagian yang lainnya atau anatomi akta tersebut merupakan satu sistem yang terintegrasi menjadi satu kesatuan.

Putusan Pengadilan Negeri Denpasar Nomor 530/Pdt.G/2016/PN. Dps., amarnya bersifat menghukum Notaris untuk segera menyelesaikan proses akta PPJB dan akta kuasa atas bidang-bidang tanah obyek sengketa yang telah ditandatangani oleh Pihak Pertama dengan masing-masing pemilik tanah sesuai dengan prosedur dan aturan hukum yang berlaku berdasarkan UU No. 2 Tahun 2014 tentang perubahan atas UU No. 30 Tahun 2004 tentang Jabatan Notaris dengan segera memberi nomor dan tanggal pada Akta Perjanjian Pengikatan Jual Beli dan Akta Kuasa. Dengan amar putusan seperti itu menunjukkan bahwa kedua akta yang dibuat dan ditandatangani oleh Pihak Pertama dihadapan Notaris (Tergugat) belum diberi nomor dan tanggal akta.

Putusan Pengadilan Negeri Denpasar yang menyebutkan segera memberikan nomor dan tanggal akta pada Akta Perjanjian Pengikatan Jual Beli dan Kuasa dapat ditafsirkan bahwa penomoran dan penanggalan akta tersebut oleh Notaris menunjuk pada jangka waktu tertentu mesti tidak secara eksplisit ditentukan jangka waktunya. Dengan demikian pada saat Notaris mengeluarkan salinan Akta Pengikatan Jual Beli dan Kuasa seharusnya tidak mengeluarkan salinan seperti salinan akta pada umumnya. Hal ini disebabkan, secara faktual pemberian nomor dan akta Perjanjian Pengikatan Jual Beli dan Kuasa tidak menggambarkan keadaan yang sebenarnya tetapi atas perintah putusan Pengadilan Negeri Denpasar kepada Notaris.

Pemberian Nomor dan tanggal pada Akta Perjanjian pengikatan Jual beli dan Akta Kuasa yang telah ditandatangani sebelumnya, maka untuk adanya karakteristik salinan Akta Perjanjian Pengikatan Jual Beli dan Akta Kuasa yang dikeluarkan Notaris atas dasar Putusan Pengadilan seharusnya salinan akta yang dikeluarkan ditegaskan pada bagian Akhir/Penutup Akta dengan formulasi kalimat yang menyebutkan DEMIKIANLAH AKTA INI, dibuat dan diresmikan pada hari dan tanggal seperti tersebut pada awal akta ini, berdasarkan Putusan Pengadilan Negeri Denpasar Nomor 530/Pdt.G/2016/PN.

Konstruksi kalimat yang menyebutkan pada hari dan tanggal seperti tersebut pada awal akta ini, adalah menunjuk bagian awal / kepala Akta Perjanjian Pengikatan Jual Beli dan Kuasa yang sudah ditandatangani sebelumnya tetapi belum diberi nomor dan tanggal akta oleh Notaris. Untuk rumusan kalimat pada awal / kepala akta tersebut dapat dibuat sebagai berikut Pada jam --------- Waktu Indonesia Bagian Tengah (WITA), hari ini, Kamis, tanggal dua puluh Oktober duaribu enambelas (20 -10 - 2016).

Pemberian nomor dan tanggal pada awal / kepala akta Perjanjian Pengikatan Jual Beli dan Kuasa, dibuat sama dengan tanggal dibacakannya putusan Pengadilan Negeri Denpasar karena kata segera 
pada diktum putusannya ditafsirkan saat itu juga diberi nomor dan tanggal. Dan putusan perdamaian memiliki kekuatan eksekutorial setelah diucapkan dalam sidang yang dinyatakan terbuka untuk umum dan bagi para pihak yang bersengketa tidak dapat menggunakan upaya hukum banding maupun kasasi.

Namun demikian, jika tidak bisa dilakukan bersamaan dengan tanggal dibacakannya putusan pengadilan, maka pemberian nomor dan tanggal akta Perjanjian Pengikatan Jual Beli dan Kuasa setidak-tidaknya berdekatan dengan tanggal Putusan Pengadilan, atau paling lambat sama dengan tanggal diterimanya salinan resmi Putusan Pengadilan Negeri Denpasar oleh Notaris yang bersangkutan

Putusan Pengadilan Negeri Denpasar Nomor 530/Pdt.G/2016/PN. Dps., bisa menjadi precedent baru dalam praktik hukum kenotariatan karena masalah penomoran dan penanggalan akta, tidak sepenuhnya menjadi wewenang Notaris melainkan bisa disepakati atau diperjanjikan kembali oleh para penghadap dengan Notaris jika pada saat penandatanganan akta dihadapan Notaris tidak serta merta diberikan nomor dan tanggal akta.

\section{SIMPULAN DAN SARAN}

\section{Simpulan}

Mengenai dasar kewenangan Pengadilan Negeri Denpasar untuk memutuskan sengketa terkait dengan Penomoran dan Penanggalan akta Notaris yang telah ditandatangani para pihak dihadapan Notaris sebagaimana Putusan Nomor 530/Pdt.G/2016/PN.Dps, secara normatif mengacu pada berbagai ketentuan peraturan perundang undangan yaitu Pasal 130 HIR / 154 Rbg, Pasal 1851 KUH Perdata, UU RI Nomor 48 Tahun 2009 tentang Kekuasaan Kehakiman, Peraturan Mahkamah Agung Republik Indonesia Nomor 1 Tahun 2016 Tentang Prosedur Mediasi di Pengadilan. Dan juga bersumber pada salah satu asas yang dikenal dalam hukum acara perdata yakni asas ius curia novit yang dinormakan ke dalam Pasal 10 ayat (1) UU RI Nomor 48 Tahun 2009 tentang Kekuasaan Kehakiman. Kemudian, mengenai penomoran dan penanggalan terhadap akta Notaris dapat dilakukan menurut ketentuan UUJNP dan berdasarkan putusan Pengadilan Negeri Denpasar dengan Nomor 530/Pdt.G/2016/PN.Dps. Untuk penomoran Akta notaris menurut ketentuan UUJN-P merupakan satu kewajiban yang dibuat secara berurut dimulai dari nomor satu dan seterusnya untuk setiap bulan, sedangkan penanggalan Akta Notaris yang disebut dalam akta adalah tanggal diresmikannya akta, yaitu dibuatnya akta, dibacakannya oleh Notaris dan ditandatanganinya oleh para penghadap saksi-saksi dan Notaris, sehingga pemberian nomor dan tanggal akta merupakan satu kesatuan untuk menjamin kepastian, ketertiban dan perlindungan hukum bagi para pihak yang berkepentingan sekaligus bagi masyarakat secara keseluruhan. Sementara itu penomoran dan penanggalan Akta Perjanjian Pengikatan Jual Beli dan Kuasa, berdasarkan Putusan Pengadilan Negeri Denpasar Nomor 530/Pdt.G/2016/PN. mesti dilakukan pada saat itu juga atau sama dengan hari dan tanggal dibacakannya putusan pengadilan, atau setidak-tidaknya berdekatan dengan hari dan tanggal Putusan Pengadilan, atau jika hal tersebut tidak dapat dilakukan maka pemberian nomor dan tanggal aktanya paling lambat sama dengan tanggal diterimanya salinan resmi Putusan Pengadilan Negeri Denpasar oleh Notaris yang bersangkutan.

\section{Saran}

Profesi Notaris merupakan profesi luhur (oficium nobile), dan jabatan Notaris adalah jabatan kepercayaan yang diberikan oleh Negara untuk melayani kepentingan masyarakat, sehingga Notaris dalam menjalankan kewenangannya mesti menerapkan prinsip kehati-hatian, senantiasa memegang teguh sumpah/janji jabatan, peraturan perundang-undangan yang berlaku khususnya UUJN jo UUJNP, dan Kode Etik Ikatan Notaris Indonesia (INI). Hendaknya Majelis Pengawas Daerah (MPD) yang diberikan kewenangan untuk melakukan pemeriksaan terhadap Protokol Notaris secara berkala, sebaiknya pada saat melakukan fungsi pengawasan tersebut lebih bersifat substantif misalnya dilakukan uji petik akta dengan maksud apakah akta yang telah dibuat memenuhi standar yang ditetapkan dalam UUJN jo UUJN-P, sehingga pemeriksaannya tidak hanya bersifat teknis administratif. Dan pada sisi lain masyarakat yang merasa dirugikan kepentingannya oleh Notaris untuk melaporkan tindakannya tersebut kepada MPD, karena pelaksanaan fungsi eksternalnya tidak dapat dilakukan jika tidak ada laporan dari masyarakat mengenai adanya dugaan pelanggaran Kode Etik Notaris atau pelanggaran ketentuan dalam UUJN jo UUJN-P. 


\section{DAFTAR PUSTAKA}

Budiono, H. (2011). Ajaran Umum Hukum Perjanjian dan Penerapannya di Bidang Kenotariatan. Bandung: PT. Citra Aditya Bakti.

Budiono, H. (2018). Demikian Akta Ini Tanya Jawab Mengenai Pembuatan Akta Notaris Di Dalam Praktik. Bandung: PT. Citra Aditya Bakti.

Hadjon, P. M. (1994). Pengkajian Ilmu Hukum Dogmatik (Normatif). Yuridika No. 6 Tahun IX, 8(1).

Harahap, Y. (2016). Hukum Acara Perdata tentang Gugatan, Persidangan, Penyitaan, Pembuktian dan Putusan Pengadilan. Jakarta: Sinar Grafika.

Laksana, I. P. G. A., \& Griadhi, N. M. A. Y. G. (2019). Kedudukan Notaris sebagai Membuat Akta dalam Bidang Pertanahan. Kertha Negara, 7(11). Retrieved from https://ojs.unud.ac.id/index.php/Kerthanegara/article/view/55031/32619

Marzuki, P. M. (2013). Penelitian Hukum (Edisi Revi). Jakarta: Kencana Prenada Media Grup.

Notodisoejo, R. S. (1982). Hukum Notariat Di Indonesia Suatu Penjelasan. Jakarta: CV. Rajawali.

Rifai, A. (2010). Penemuan Hukum oleh Hakim dalam Persfektif Hukum Progresif. Jakarta: Sinar Grafika.

Sjaifurrachman. (2011). Aspek Pertanggungjawaban Notaris dalam Pembuatan Akta. Bandung: Mandar Maju.

Soekanto, S., \& Mamudji, S. (2001). Penelitian Hukum Normatif: Suatu Tinjauan Singkat. Jakarta: PT. Raja Grafindo Persada. 